\title{
HUBUNGAN LOKASI DAN PROMOSI DENGAN KEPUTUSAN PEMBELIAN RUMAH SUBSIDI PADA PT. GRAHA ESTETIKA PROPERTY BENGKULU
}

\author{
Sri Handayani \\ iiehandayani@gmail.com \\ Miko Warodei Antono \\ Fakultas Ekonomi Universitas Dehasen Bengkulu
}

\begin{abstract}
The purpose of this study was to determine the relationship between location and the decision to purchase a subsidy at PT. Graha Estetika Property Bengkulu and to find out the relationship of promotion with the decision to purchase a subsidized house at PT. Graha Estetika Property Bengkulu. The method of analysis uses Spearman rank correlation and hypothesis testing.
\end{abstract}

Spearman rank correlation coefficient on location relationship (X1) with subsidized house purchase decision (Y) at PT. The Bengkel Property Aesthetic Graha is known that the value of rho count $=0.85$ means the relationship between the location and the decision to purchase a subsidy at PT. Bengkulu's Graha Estetika Property is very strong, because the correlation value is in the coefficient interval of 0.800 - 1,000. The value of the Spearman rank correlation coefficient on the relationship of promotion (X2) with the decision to purchase a subsidized house (Y) at PT. Bengkel Property Aesthetic Graha is known the value of rho count $=0.68$ the meaning of the promotion relationship with the purchase of a house subsidy decision at PT. Bengkulu's Graha Aesthetic Property is strong, because the correlation value is in the coefficient interval of $0.600-799$.

Keywords: Location, Promotion, Purchase Decision.

\section{PENDAHULUAN}

\section{Latar Belakang}

Salah satu kebutuhan yang mendasar adalah masalah perumahan. Tiap manusia membutuhkan rumah untuk tempat berlindung dan sebagai tempat berkumpul dan berlangsungnya aktivitas keluarga sekaligus sebagai sarana investasi. Kini sebuah rumah tak cukup hanya untuk berteduh namun juga 
dituntut untuk mengakomodir kebutuhan dan keinginan pemiliknya. Seperti lokasi yang strategis, bangunan yang bagus dan kokoh serta lingkungan yang nyaman. Terwujudnya kesejahteraan masyarakat dan sumber daya manusia yang berkualitas dapat ditandai dengan meningkatnya kualitas kehidupan yang layak huni. Pilihan masyarakat dalam memiliki rumah dapat dilakukan dengan cara membeli secara tunai atau angsuran yang dapat diperoleh melalui pasar properti.

Seorang konsumen merupakan salah satu unsur yang sangat menentukan keberhasilan perusahaan dalam mencapai tujuannya, tanpa adanya konsumen sudah dapat dipastikan bahwa transaksi tidak ada, dan sudah dipastikan pula bahwa perusahaan tersebut adalah perusahaan yang bangkrut. Oleh karena itu maka perusahaan sangat tergantung pada konsumen, sehingga tugas perusahaan untuk mengetahui bagaimana minat beli konsumen menjadi sangat penting, perusahaan harus memiliki kemampuan untuk memberikan rangsangan kepada konsumen agar konsumen memiliki minat beli dimana konsumen bersedia dan merasa butuh untuk membeli produk.

Proses dalam pemasaran haruslah mempunyai strategi yang terintegrasi dan jelas guna merancang pasar dengan sebaik-baiknya. Masalah yang sering menjadi sebuah faktor penting dalam upaya merancang strategi pasar dengan penjualan yang efektif dan sesuai dengan harapan salah satunya adalah masalah dalam pemilihan lokasi usaha dimana masalah pemilihan lokasi usaha yang tepat merupakan salah satu faktor penunjang suksesnya suatu usaha. Dalam pemilihan lokasi usaha yang tepat diperlukan pertimbangan faktor obyektif dan faktor subyektif yang tepat. Permasalahan ini akan muncul ketika manusia dihadapkan pada beberapa alternatif lokasi dan beberapa parameter lokasi yang menyertai alternatif lokasi tersebut. Memilih lokasi merupakan keputusan penting untuk bisnis yang harus membujuk konsumen untuk datang ke tempat penjualan dalam pemenuhan kebutuhannya.Bagi seorang yang ahli dalam hal pemilihan lokasi maka permasalahan ini akan tampak lebih mudah, walaupun dalam kenyataannya tetap saja menyulitkan. Dan kadang kala karena ketidakstabilan manusia (sifat alamiah manusia) dalam memberikan pertimbangan, solusi yang diberikan menjadi tidak tepat.

Menurut Swastha (2008:24) lokasi adalah tempat dimana suatu usaha atau aktivitas usaha dilakukan. Faktor penting dalam pengembangan suatu usaha adalah letak lokasi terhadap daerah perkotaan, cara pencapaian dan waktu tempuh lokasi ke tujuan. Faktor lokasi yang baik adalah relatif untuk setiap jenis usaha yang berbeda. 
Terdapat banyak hal yang menjadi suatu dasar dalam penentuan suatu lokasi usaha, dan lokasi yang ditentukanpun bergantung pada jenis bisnis yang dijalani oleh pebisnis, untuk keputusan lokasi industri, strategi yang digunakan biasanya adalah strategi untuk meminimalkan biaya, meski inovasi dan kreativitas juga penting.

Selain pemilihan lokasi usaha, perusahaan juga membutuhkan komunikasi dengan konsumennya yaitu dengan cara melakukan promosi, semakin gencar perusahaan melakukan promosi maka akan semakin dekat di benak konsumennya. Oleh karena itu banyak perusahaan yang berani mengeluarkan anggaran yang cukup besar untuk biaya promosi.Banyak sekali sarana atau media promosi yang dapat digunakan sebagai media memperkenalkan produk yang ditawarkan. Efektivitas dan efisiensi suatu media promosi tidak hanya didasarkan pada pertimbangan finansial dan waktu saja. Namun efektivitas dan efisiensi tersebut lebih ditekankan pada kemampuan media promosi dalam menarik minat calon konsumen untuk lebih mengenal produk yang ditawarkan dan pada akhirnya calon konsumen memutuskan untuk membeli produk yang ditawarkan tersebut. Media atau alat promosi yang sering dilakukan perusahaan antara lain melalui: periklanan, penjualan personal, pemasaran langsung, hubungan masyarakat, dan promosi penjualan.Alat-alat promosi tersebut dapat digunakan sesuai dengan kebutuhan dan kemampuan dari perusahaan itu sendiri.

Untuk itu perlu adanya informasi yang diiringi dengan jasa/pelayanan lainnya, yang dapat disajikan dalam bentuk promosi seperti periklanan, promosi penjualan, publisitas, personal selling yang tujuannya adalah agar konsumen tertarik dan memutuskan untk membeli produk tersebut.

PT. Graha Estetika Property Bengkulu merupakan sebuah perusahaan yang bergerak mencari keuntungan dibidang properti, dan produk yang ditawarkan oleh PT. Graha Estetika Property Bengkulu adalah rumah subsidi. PT. Graha Estetika Property Bengkulu telah melakukan berbagai macam bentuk promosi produk barang maupun jasa telekomunikasinya yang disajikan melalui iklan, promosi penjualan, personal selling, pemasaran langsung serta publisitas/hubungan masyarakat yang dimuat/diberitakan melalui berbagai media seperti televisi, media cetak seperti surat kabar, brosur serta media lainnya seperti papan reklame ditepi jalan, depan toko, spanduk dan sebagainya. PT. Graha Estetika Property Bengkulu telah memiliki pengetahuan untuk meningkatkan minat beli masyarakat terhadap rumah yang ditawarkan oleh PT. Graha Estetika Property Bengkulu, akan tetapi masalah mendasar yang kerap terjadi di Kota Bengkulu dan sekitarnya adalah sulitnya mendapatkan konsumen yang memiliki komitmen untuk melakukan pembelian rumah, terlebih masyarakat merasa bahwa harga 
rumah tidaklah murah. Permasalahan lain yang sering terjadi dalam bisnis penjualan rumah subsidi adalah banyaknya kompetitor yang menjadi pesaing. Dengan banyaknya kompetitor yang ada maka tingkat kesulitan PT. Graha Estetika Property Bengkulu untuk memperoleh konsumen semakin sulit, selain itu kendala dalam penjualan rumah subsidi adalah aturan bunga yang diajukan oleh perusahaan sehingga konsumen merasa takut dan sangat konservatif dalam memilih perusahaan mana yang cocok bagi konsumen dalam memutuskan membeli sebuah rumah subsidi.

\section{Lokasi}

\section{TINJAUAN PUSTAKA}

Lokasi adalah tempat dimana suatu usaha atau aktivitas usaha dilakukan(Swastha, 2008:24). Faktor penting dalam pengembangan suatu usaha adalah letak lokasi terhadap daerah perkotaan, cara pencapaian dan waktu tempuh lokasi ke tujuan. Faktor lokasi yang baik adalah relatif untuk setiap jenis usaha yang berbeda.

Alma (2011:103) mengemukakan bahwa "Lokasi adalah tempat perusahaan beroperasi atau tempat perusahaan melakukan kegiatan untuk menghasilkan barang dan jasa yang mementingkan segi ekonominya". Sedangkan pengertian lokasi menurut Kasmir (2009:129) yaitu "Tempat melayani konsumen, dapat pula diartikan sebagai tempat untuk memajangkan barangbarang dagangannya".

Menurut Kotler (2008:51) salah satu kunci menuju sukses adalah lokasi, lokasi dimulai dengan memilih komunitas.Keputusan ini sangat bergantung pada potensi pertumbuhan ekonomis dan stabilitas, persaingan, iklim politik, dan sebagainya.

Lamb et al., (2010:63) menyatakan bahwa memilih tempat atau lokasi yang baik merupakan keputusan yang penting, karena :

a. Tempat merupakan komitmen sumber daya jangka panjang yang dapat mengurangi fleksibilitas masa depan usaha.

b. Lokasi akan mempengaruhi pertumbuhan di masa depan. Area yang dipilih haruslah mampu untuk tumbuh dari segi ekonomi sehingga ia dapat mempertahankan kelangsungan hidup usaha.

c. Lingkungan setempat dapat saja berubah setiap waktu, jika nilai lokasi memburuk, maka lokasi usaha harus dipindahkan atau ditutup. 
Lokasi menurut Lupiyoadi (2009:42), berhubungan dengan di mana perusahaan harus bermarkas dan melakukan operasi atau kegiatannya. Dalam hal ini ada tiga jenis interaksi yang mempengaruhi lokasi, yaitu:

a. Konsumen mendatangi pemberi jasa (perusahaan): apabila keadaannya seperti ini maka lokasi menjadi sangat penting. Perusahaan sebaiknya memilih tempat dekat dengan konsumen sehingga mudah dijangkau, dengan kata lain harus strategis.

b. Pemberi jasa mendatangi konsumen: dalam hal ini lokasi tidak terlalu penting, tetapi yang harus diperhatikan adalah penyampaian jasa harus tetap berkualitas.

c. Pemberi jasa dan konsumen tidak bertemu secara langsung: berarti penyedia jasa dan konsumen berinteraksi melalui sarana tertentu seperti telepon, komputer, atau surat. Dalam hal ini lokasi menjadi sangat tidak penting selama komunikasi antara kedua pihak terlaksana dengan baik.

Adapun faktor-faktor yang harus dipertimbangkan dalam menentukan daerah pembelanjaan adalah luas daerah perdagangan, dapat dicapainya dengan mudah, potensi pertumbuhannya, lokasi toko-toko saingan. Sedangkan keputusan tentang lokasi toko di dalam pusat pembelanjaan dipengaruhi oleh beberapa faktor yang lebih spesifik seperti biaya dan lamanya sewa, pelayanan yang diberikan oleh pengusaha pusat pembelanjaan, luas ruangan beserta layoutnya, arus pengunjung, jarak dari tempat parkir (Swasta dan Irawan,2003:339).

\section{Promosi}

Promosi merupakan alat komunikasi dengan konsumen dan calon konsumen,walaupun sampai aat ini masih ada beberapa perusahan yang masih mengandalkan satu atau dua alat promosi untuk mencapai tujuan komunikasinya, hal tersebut tergantung pada kebutuhan dan kemampuan perusahaan.

Menurut Mursid (2005:95) promosi adalah komunikasi yang persuasif, mengajak, mendesak, membujuk, meyakinkan. Ciri dari komunikasi yang persuasif adalah ada komunikator yang secara terencana mengatur berita dan cara penyampaiannya untuk mendapatkan akibat tertentu dalam sikap dan tingkah laku si penerima. 
Menurut Saladin dan Yevis Marty Oesman (2004:194), Promosi adalah kombinasi dari penjualan tatap muka, periklanan, promosi penjualan, publisitas dan hubungan yang membantu pencapaian tujuan perusahaan".

Menurut Stanton dalam bukunya Prinsip Pemasaran, alih bahasa Lamarto (2006:136) "Promosi adalah kombinasi dari penjualan tatap muka, periklanan, promosi penjualan, publisitas dan hubungannya yang membantu pencapaian tujuan perusahaan."

Sementara dalam buku Principles Marketing yang alih bahasa oleh Sihombing (2010:111), Kotler dan Armstrong mendefinisikan promosi sebagai perpaduan khusus antara iklan, penjualan pribadi, promosi penjualan, dan hubungan masyarakat yang digunakan perusahaan untuk meraih tujuan iklan dan pemasarannya"

Dari tiga definisi tersebut dapat ditarik kesimpulan bahwa promosi adalah penggunaan lebih dari satu alat promosi untuk menjamin tercapainya tujuan promosi dan komunikasi antara produsen dengan konsumen. Alat promosi yang digunakan adalah periklanan, penjualan personal, pemasaran langsung, promosi penjualan dan hubungan masyarakat.

Alat promosi yang dijadikan ukuran dalam mengkomunikasikan produk menurut Kotler dan Armstrongalih bahasa Teguh (2007:643) adalah :

\section{a. Periklanan (Advertising)}

Periklanan dapat digunakan untuk membangun citra jangka panjang bagi suatu produk, dan sisi lain, mempercepat penjualan.Periklanan dapat secara efisien menjangkau berbagai pembeli yang tersebar secara geografis.Semua bentuk penyajian dan promosi nonpersonal atas ide, barang atau jasa yang dilakukan oleh perusahaan sponsor tertentu. Karena banyaknya bentuk dan penggunaan periklanan, sangat sulit untuk membuat generalisasi yang merangkum semuanya, akan tetapi sifat-sifat periklanan berikut ini dapat diperhatikan :

1. Generalisasi umum

Periklanan yang bersifat umum memberikan semacam keabsahan pada produk dan menyarankan tawaran yang terstandarisasi, karena banyak orang menerima pesan yang sama, pembeli mengetahui bahwa motif mereka untuk membeli produk terebut akan dimaklum oleh umum.

2. Tersebar luas.

Periklanan merupakan media yang mempunyai daya sebar yang luas sehingga memungkinkan penjual mengulang pesan berkali-kali. Iklan juga 
memungkinkan pembeli menerima dan membandingkan pesan dari berbagai pesaing.

3. Ekspresi yang lebih kuat.

Periklanan memberikan peluang untuk mendramatisasi perusahaan dan produknya melalui penggunaan cetakan, suara, dan warna yang penuh seni.

4. Tidak bersifat pribadi.

Audiens tidak merasa wajib untuk memperhatikan atau menanggapi.Iklan hanya mampu melakukan monolog, bukan dialog dengan audiens.

Pemilihan jenis media yang akan digunakan merupakan salah satu keputusan penting bagi sponsor. Setiap media mempunya ciri-ciri tersendiri yang berbeda. Jenis-jenis media tersebut adalah :

\section{1) Surat kabar}

Surat kabar ini merupakan media periklanan yang dapat dicapai masyarakat luas karena harganya relatif murah. Sebagai media yang dapat dilihat atau dibaca, surat kabar ini mudah ini menjadi basi (beritanya) sehingga masyarakat tidak ingin membacanya.

\section{2) Majalah}

Dapat dikatakan bahwa pembaca majalah ini lebih selektif atau terbatas dibandingkan dengan surat kabar. Tidak semua orang ingin membaca majalah, biasanya biaya iklan dimajalah lebih mahal daripada di surat kabar, namun dapat dinikmati lebih lama serta dapat mengemukakan gambar berwarna yang lebih menarik.

\section{3) Radio}

Sebagai media yang hanya dapat dinikmati melalui pendengaran ini, radio dapat menjangkau daerah yang luas dan dapat diterima oleh segala lapisan masyarakat.

\section{4) Televisi}

Televisi ini merupakan media yang dapat memberikan kombinasi antara suara dengan gambar yang bergerak dan dapat dinikmati oleh siapa saja.Namun demikian biaya iklan pada televisi ini relatif tinggi dan hanya dapat dinikmati sebentar.

5) Pos langsung 
Media periklanan yang dapat dimasukkan kedalam pos langsung atau direct mailadalah : kartu pos, buku kecil, surat edaran, brosur dan sebagainya.

Selain media periklanan yang telah disebutkan dimuka, masih ada lagi media periklanan lainnya yang dapat digunakan yaitu papan reklame (ditepi jalan, depan toko), spanduk dan sebagainya.

\section{b. Penjualan Personal (Personal Seling)}

Interaksi langsung dengan satu calon pembeli atau lebih, guna melakukan presentasi, menjawab pertanyaan, dan menerima pesanan. Tahap yang dilakukan oleh perusahaan dalam mengelola tenaga penjual (Kotler dan Armstrong, alih bahasa Teguh (2007:644) : adalah :1)Merancang strategi penjualan,2)Merekrut dan menyeleksi tenaga penjual,3)Melatih tenaga penjual,4)Memberi kompensasi tenaga penjualan,5)Mensuvervisi tenaga penjual, 5)Mengevaluasi tenaga penjual.

Penjualan personil memiliki tiga ciri khusus (Kotler dan Armstrongalih bahasa Teguh (2007:644) yaitu :

1) Konfrontasi personal. Penjualan personal mencakup hubungan yang hidup, langsung dan interaktif antara dua orang atau lebih. Masingmasing pihak dapat mengobservasi reaksi dari pihak lain yang lebih dekat.

2) Mempererat. Penjualan personal memungkinkan timbulnya berbagai jenis hubungan mulai dari hubungan penjualan sampai hubungan persahabatan. Wiraniaga biasanya sudah benar-benar mengetahui minat pelanggan yang terbaik.

3) Tanggapan. Penjualan personal membuat pembeli merasa berkewajiban untuk mendengarkan pembicaraan wiraniaga.

\section{c. Pemasaran Langsung (Dirrect Selling)}

Penggunaan surat, telepon, faksmil, email, dan alat penghubung nonpersonal lain untuk berkomunikasi secara langsung dengan atau mendapatkan tanggapan langsung dari pelanggan dan calon pelanggan tertentu. Meskipun beragam bentuknya, karakter umum dari pemasaran langsung adalah sebagai berikut (Kotler dan Armstrong, alih bahasa Teguh (2007:645) :

1. Nonpublik, pesan biasanya ditujukan kepada orang tertentu.

2. Disesuaikan, pesan dapat disiapkan untuk menarik orang yang dituju. 
3. Terbaru, pesan dapat disiapkan dengan sangat cepat dan sesuai kondisi.

4. Interaktif, pesan dapat diubah tergantung pada tanggapan orang tersebut.

\section{d. Promosi Penjualan (Sales Promotion)}

Promosi penjualan diartikan sebagai kegiatan komuniaksi antara perusahaan dan konsumen sebagai usaha mempengaruhi konsumen dalam kegiatan pembelian sesuai keinginan dan kebutuhannya. Berbagai insentif jangka pendek untuk mendorong keinginan mencoba atau membeli suatu produk atau jasa. Jenis-jenis alat promosi penjualan menurut Kotler dan Armstrong alih bahasa Teguh (2007:684) yaitu :

1) Kupon yaitu sertifikat yang memberi pembeli potongan harga untuk pembelian produk tertentu.

2) Kontes, undian, permainan yaitu kegiatan promosi yang memberi konsumen peluang untuk memenangkan sesuatu seperti uang atau barang, entah dengan keberuntungan atau dengan usaha ekstra.

3) Sampel yaitu sejumlah kecil produk yang ditawarkan kepada kosnsumen untuk dicoba.

4) Tawaran pengembalian uang (rabat)

5) Paket harga yaitu pengurangan harga yang dicantumkan oleh produsen langsung pada label atau kemasan.

6) Hadiah yaitu barang yang ditawarkan secara cuma-cuma atau dengan harga sangat miring sebagai insentif untuk membeli suatu produk.

7) Penghargaan atas kesetiaan

8) Barang promosi memberikan barang secara cuma - cuma yang berkaitan dengan produk yang dijual.

9) Menyediakan titik/pusat pembelian yang tidak permanen untuk produk yang sedang dipromosikan.

\section{Publicity)}

e. Hubungan Masyarakat dan Publisitas (Public Relation and

Berbagai program untuk mempromosikan dan/atau melindungi citra perusahaan atau masing-masing produknya. Departemen hubungan 
masyarakat biasanya melakukan fungsi-fungsi dibawah ini (Kotler dan Armstrong, alih bahasa Teguh (2007:644) ):

a. Hubungan pers dan aktivitas pers yaitu menciptakan dan menempatkan informasi bernilai berita dalam media untuk menarik perhatian terhadap orang, produk, atau jasa.

b. Publisitas produk, yaitu mempublikasikan produk tertentu (terutama produk baru) kepada masyarakat.

c. Kegiatan masyarakat yaitu memupuk dan mempertahankan hubungan komunitas nasional atau lokal.

d. Melobi, yaitu membangun dan mempertahankan hubungan dengan anggota birokrasi/pemerintahaan.

e. Hubungan investor yaitu mempertahankan hubungan dengan pemegang saham dan relasi bisnis lainnya.

\section{Keputusan Pembelian}

Keputusan pembelian merupakan hal yang sangat mutlak yang harus diperoleh oleh para pelaku bisnis agar apa yang telah diupayakan akan dapat mencapai hasil yang sesuai dengan harapan. Menurut Kotler dan Armstrong (2004:227) mengemukakan bahwa "keputusan pembelian adalah tahap proses keputusan dimana konsumen secara aktual melakukan pembelian produk". Menurut Kotler dan Armstrong (2004:224), proses pengambilan keputusan pembelian terdiri dari lima tahap: Pengenalan kebutuhan, Pencarian informasi, Pengevaluasian alternatif, Keputusan pembelian, Perilaku setelah pembelian.

Sunyoto (2013:86) mengkonsepkan tiga hal penting setelah kita dapat memahami model keputusan pembelian, adapun ketiga konsep tersebut adalah sebagai berikut :

a. Dengan adanya model, pandangan terhadap perilaku konsumen bisa dilihat dalam perspektif yang terintegrasi.

b. Model keputusan pembelian konsumen dapat dijadikan dasar untuk pengembangan strategi pemasaran yang efektif

c. Model keputusan pembelian konsumen dapat dijadikan dasar untuk segmentasi dan positioning. 
Sikap pembelian konsumen seringkali diawali dan dipengaruhi oleh banyaknya rangsangan dari luar dirinya, baik berupa rangsangan pemasaran maupun rangsangan dari lingkungannya. Rangsangan tersebut kemudian diproses dalam diri sesuai dengan karakteristik pribadinya, sebelum akhirnya diambil keputusan pembelian. Karakteristik pribadi konsumen yang dipergunakan untuk memproses rangsangan tersebut sangat komplek, dan salah satunya adalah motivasi konsumen untuk membeli.

\section{HASIL PENELITIAN DAN PEMBAHASAN}

\section{A. Hasil Penelitian}

1. Hubungan Lokasi dan Promosi dengan Keputusan Pembelian Rumah Subsidi pada PT. Graha Estetika Property Bengkulu

Untuk mengetahui korelasi antar variabel yang diteliti maka peneliti menggunakan analisis korelasi Spearman Rank. Berikut merupakan penjabaran analisis korelasi spearman rank untuk mengetahui hubungan lokasi (X1) dan promosi (X2) dengan keputusan pembelian (Y) pada PT. Graha Estetika Property Bengkulu:

a. Analisis hubungan lokasi (X1) dengan keputusan pembelian rumah subsidi (Y) pada PT. Graha Estetika Property Bengkulu

Dari tabel penolong untuk menghitung koefisien korelasi spearman rank pada variabel X1 dan variabel Y (lampiran 8) diketahui nilai $\sum \mathrm{bi}^{2}=4.174$.

$$
\begin{aligned}
\rho & =1-\frac{6 \sum b_{i}{ }^{2}}{n\left(n^{2}-1\right)} \\
& =1-\frac{6 \times 4.174}{55\left(55^{2}-1\right)} \\
& =1-\frac{25.044}{55 \times 3.024} \\
& =1-\frac{25.044}{166.320} \\
& =1-0,15 \\
& =0,85
\end{aligned}
$$

Berdasarkan perhitungan koefisien korelasi, nilai rho $(\rho)$ hitung $=0,85$ artinya hubungan variabel lokasi dengan keputusan pembelian rumah subsidipada PT. Graha Estetika Property Bengkuluadalahsangat kuat, karena nilai korelasi berada pada interval koefisien 0,800 - 1,000.

b. Analisis promosi (X2) dengan keputusan pembelian rumah subsidi (Y) pada PT. Graha Estetika Property Bengkulu: 
Dari tabel penolong untuk menghitung koefisien korelasi spearman rank pada variabel X2 dan variabel Y (lampiran 9) diketahui nilai $\sum \mathrm{bi}^{2}=8.929$

$$
\begin{aligned}
\rho & =1-\frac{6 \sum b_{i}^{2}}{n\left(n^{2}-1\right)} \\
& =1-\frac{6 \times 8.929}{55\left(55^{2}-1\right)} \\
& =1-\frac{53.574}{55 \times 3.024} \\
& =1-\frac{53.574}{166.320} \\
& =1-0,32 \\
& =0,68
\end{aligned}
$$

Berdasarkan perhitungan koefisien korelasi, nilai rho $(\rho)$ hitung $=0,68$ artinya hubungan variabel promosi dengan keputusan pembelian rumah subsidipada PT. Graha Estetika Property Bengkulu adalahkuat, karena nilai korelasi beradapada interval koefisien 0,600-0,799.

\section{Uji Hipotesis}

Untuk membuktikan apakah hipotesis yang diajukan dalam penelitian ini terbukti atau tidak maka digunakan penentuan uji hipotesis, dengan ketentuan berikut ini :

a. Level of significant atau tingkat keyakinan sebesar $95 \%$ dan tingkat penyimpangan atau $\alpha$ (Alpha) $=0,05$

b. Pengujian hipotesis menggunakan rumus thitung sebagai berikut:

1. Uji hipotesis hubungan lokasi dengan keputusan pembelian rumah subsidipada PT. Graha Estetika Property Bengkulu:

$$
\begin{aligned}
& \text { thitung }=r \sqrt{\frac{n-2}{1-r^{2}}} \\
& \mathrm{t} \text { hitung }=0,85 \sqrt{\frac{55-2}{1-(0,85)^{2}}} \\
& \mathrm{t} \text { hitung }=0,85 \sqrt{\frac{53}{1-0,72}} \\
& \mathrm{t} \text { hitung }=0,85 \sqrt{\frac{53}{0,28}} \\
& \mathrm{t} \text { hitung }=0,85 \mathrm{x} 13,758 \\
& \mathrm{t} \text { hitung }=11,694 \\
& \text { Nilai } \mathrm{t} \text { hitung }=11,694 \text { artinya } \mathrm{t} \text { hitung lebih besar dari } \mathrm{t} \text { tabel }= \\
& \text { 1,674berarti } \quad \text { kesimpulan Ho ditolak Ha diterima, artinya ada }
\end{aligned}
$$


hubungan positif dan signifikan antara lokasidengan keputusan pembelian rumah subsidipada PT. Graha Estetika Property Bengkulu.

2) Uji hipotesis hubungan promosi dengan keputusan pembelian rumah subsidipada PT. Graha Estetika Property Bengkulu:

$$
\begin{aligned}
& \text { thitung }=r \sqrt{\frac{n-2}{1-r^{2}}} \\
& \text { t hitung }=0,68 \sqrt{\frac{55-2}{1-(0,68)^{2}}} \\
& \mathrm{t} \text { hitung }=0,68 \sqrt{\frac{53}{1-0,46}} \\
& \mathrm{t} \text { hitung }=0,68 \sqrt{\frac{53}{0,54}} \\
& \text { thitung }=0,68 \times 9,906 \\
& \text { thitung }=6,736 \\
& \text { Nilai } \mathrm{t} \text { hitung }=6,736 \text { artinya } \mathrm{t} \text { hitung lebih besar dari } \mathrm{t} \\
& \text { tabel }=1,674 \text { berarti kesimpulan Ho ditolak Ha diterima, } \\
& \text { artinya ada hubungan positif dan signifikan antara promosi } \\
& \text { dengan keputusan pembelian rumah subsidipada PT. Graha } \\
& \text { Estetika Property Bengkulu. }
\end{aligned}
$$

\section{B. Pembahasan}

Berdasarkan hasil penelitian dan pembahasan diperoleh perhitungan korelasi rank spearman dan pengujian hipotesis sebagaimana pada tabel berikut ini :

Tabel 7. Rekap Hasil Penelitian dengan Perhitungan Korelasi dan Uji Hipotesis antara lokasi (X1) dengan keputusan pembelian (Y)

\begin{tabular}{|l|l|l|l|l|c|}
\hline \multicolumn{1}{|c|}{ Variabel } & $\begin{array}{l}\text { Korelasi Rank } \\
\text { Spearman }(\rho)\end{array}$ & Kriteria & t hitung & t tabel & Kriteria \\
\hline $\begin{array}{l}\text { Lokasi (X1) dan } \\
\text { keputusan } \\
\text { pembelian } \\
\text { rumah } \\
\text { subsidi(Y) }\end{array}$ & 0,85 & $\begin{array}{l}\text { Sangat } \\
\text { Kuat }\end{array}$ & 11,694 & 1,674 & Signifikan \\
\hline
\end{tabular}

Sumber : Hasil Penelitian, Diolah, 2018

Dalam analisis korelasi rank spearman terhadap hubungan lokasi dengan keputusan pembelian rumah subsidi (Y) pada PT. Graha Estetika Property Bengkulu diperoleh nilai 0,85 kriteria sangat kuat karena hasil korelasinya terletak pada interval koefisien antara 0,800 - 1,000. Dari hasil uji hipotesis 
hubungan antara lokasi dengan dengan keputusan pembelian rumah subsidi (Y) pada PT. Graha Estetika Property Bengkulu adalah diperoleh t hitung 11,694 artinya bahwa lokasi (X1) mempunyai hubungan signifikan dengan keputusan pembelian rumah subsidi (Y) pada PT. Graha Estetika Property Bengkulu karena nilai t hitung lebih besar dari t tabel $(1,674)$.

Tabel 8. Rekap Hasil Penelitian dengan Perhitungan Korelasi dan Uji Hipotesis antara promosi (X2) dengan keputusan pembelian (Y)

\begin{tabular}{|l|l|l|l|l|c|}
\hline \multicolumn{1}{|c|}{ Variabel } & $\begin{array}{l}\text { Korelasi Rank } \\
\text { Spearman }(\rho)\end{array}$ & Kriteria & t hitung & t tabel & Kriteria \\
\hline $\begin{array}{l}\text { Promosi (X2) } \\
\text { dan keputusan } \\
\text { pembelian } \\
\text { rumah subsidi } \\
(Y)\end{array}$ & 0,68 & Kuat & 6,736 & 1,674 & Signifikan \\
\end{tabular}

Sumber : Hasil Penelitian, Diolah, 2018

Dalam analisis korelasi rank spearman terhadap promosi dengan keputusan pembelian rumah subsidi (Y) pada PT. Graha Estetika Property Bengkulu diperoleh nilai 0,68 kriteria kuat karena hasil korelasinya terletak pada interval koefisien antara 0,600 - 0,799. Dari hasil uji hipotesis hubungan antara promosi dengan keputusan pembelian rumah subsidi(Y) pada PT. Graha Estetika Property Bengkuludiperoleh t hitung adalah 6,736 artinya bahwa promosi (X2) mempunyai hubungan signifikandengan keputusan pembelian rumah subsidi(Y) pada PT. Graha Estetika Property Bengkulu karena nilai t hitung lebih besar dari t tabel $(1,674)$.

Mengingat bahwa lokasi mempunyai hubungan yang sangat kuat dengan keputusan pembelian rumah subsidi pada PT. Graha Estetika Property Bengkulu maka tentunya dalam membuka usaha harus memperhatikan lokasi yang strategis agar mudah dilalui atau dijangkau, hal ini sesuai dengan pendapat Tjiptono (2006:92 bahwa lokasi usaha maupun produk yang dijual haruslah mudah dilihat sebab dengan memperhatikan hal tersebut tentulah akan menjadi pertimbangan konsumen untuk memutuskan membeli produk yang ditawarkan atau dijangkau sarana transportasi umum.Karena itu Pemilihan lokasi merupakan faktor penting yang berpengaruh terhadap kesuksesan suatu usaha, karena pemilihan lokasi juga berhububungan dengan keputusan pembelian konsumen.

Selain lokasi tentunya faktor promosipun harus mendapat perhatian dari pihak pimpinan usaha karena promosi merupakan alat komunikasi dengan konsumen dan calon konsumen,walaupun sampai saat ini masih ada beberapa perusahaan yang masih mengandalkan satu atau dua alat promosi 
untuk mencapai tujuan komunikasinya, hal tersebut tergantung pada kebutuhan dan kemampuan perusahaan, oleh karena itu banyak pilihan ataupun gabungan cara promosi yang dapat dilakukan sebagaimana dikemukakan oleh Teguh(2007:643)yaitu periklanan, penjualan personal, pemasaran langsung, promosi penjualan dan hubungan masyarakat. Semakin gencar perusahaan melakukan promosi maka akan semakin dekat di benak konsumennya. Oleh karena itu banyak perusahaan harus berani mengeluarkan anggaran yang cukup besar untuk biaya promosi.Banyak sekali sarana atau media promosi yang dapat digunakan sebagai media memperkenalkan produk yang ditawarkan. Efektivitas dan efisiensi suatu media promosi tidak hanya didasarkan pada pertimbangan finansial dan waktu saja. Namun efektivitas dan efisiensi tersebut lebih ditekankan pada kemampuan media promosi dalam menarik minat calon konsumen untuk lebih mengenal produk yang ditawarkan dan pada akhirnya calon konsumen memutuskan untuk membeli produk yang ditawarkan tersebut. Alat maupun media promosi tersebut dapat digunakan sesuai dengan kebutuhan dan kemampuan dari perusahaan itu sendiri.Untuk itu perlu adanya informasi yang diiringi dengan jasa/pelayanan lainnya, yang dapat disajikan dalam bentuk promosi seperti periklanan, promosi penjualan, publisitas, personal selling yang tujuannya adalah agar konsumen tertarik dan memutuskan untuk membeli produk tersebut.

\section{KESIMPULAN DAN SARAN}

\section{Kesimpulan}

Berdasarkan dari hasil penelitian mengenai hubungan lokasi dan promosi dengan keputusan pembelian rumah subsidi pada PT. Graha Estetika Property Bengkuluyaitu :

1. Nilai koefisien korelasi spearman rankhubungan lokasi (X1) dengan keputusan pembelian rumah subsidi (Y) pada PT. Graha Estetika Property Bengkuludiketahui sebesar $=0$,85artinya hubungan lokasi dengan dengan keputusan pembelian rumah subsidi pada PT. Graha Estetika Property Bengkuluadalah sangat kuat, karena nilai korelasi berada pada interval koefisien $0,800-1,000$.

2. Nilai koefisien korelasi spearman rankhubungan promosi (X2) dengan keputusan pembelian rumah subsidi (Y) pada PT. Graha Estetika Property Bengkulusebesar $=0,68$ artinya hubungan promosi dengan dengan keputusan pembelian rumah subsidi pada PT. Graha Estetika 
Property Bengkulu adalah kuat, karena nilai korelasi berada pada interval koefisien 0,600-0,799.

3. Uji hipotesis antara lokasi (X1) dengan dengan keputusan pembelian rumah subsidi (Y) pada PT. Graha Estetika Property Bengkulu diperoleh nilai $t$ hitung lebih besar dari $t$ tabel $(11,694>1,674)$ sehingga disimpulkan lokasi mempunyai hubungan signifikan dengan keputusan pembelian rumah subsidi (Y) pada PT. Graha Estetika Property Bengkulu.

4. Uji hipotesis antara promosi (X2) dengan dengan keputusan pembelian rumah subsidi (Y) pada PT. Graha Estetika Property Bengkulu diperoleh nilai $t$ hitung lebih besar dari $t$ tabel $(6,736>1,674)$ sehingga disimpulkan promosi mempunyai hubungan signifikan dengan keputusan pembelian rumah subsidi pada PT. Graha Estetika Property Bengkulu.

\section{Saran}

Diharapkan pihak PT. Graha Estetika Property Bengkulu terus meningkatkan promosi kepada calon pembeli dan pembeli perumahan yang ditawarkan PT. Graha Estetika Property dengan subsidi yang menarik, prosedur yang mudah dan pelayanan yang lebih baik lagi. Selain itu juga sebaiknya PT. Graha Estetika Property terus berupaya untuk menawarkan produk rumah yang modern dan harga yang sesuai/terjangkau oleh masyarakat yang berminat membeli rumah subsidi sertalokasi yang strategis.

Faktor budaya yang dapat mempengaruhi keputusan pembelian adalah budaya yang ada diseputar usaha dalam hal ini yang ada di lingkungan perumahan adalah budaya yang dapat diterima oleh masyarakat serta masyarakat sekitar dapat mentoleransi perbedaan agama yang dianut oleh masyarakat sekitar perumahan. Dalam hal faktor sosial yang dapat mempengaruhi keputusan pembelian adalah juga adanya rekomendasi dari kerabat atau teman mengenai rumah yang akan dibeli artinya kerabat atau keluarga mendukung konsumen untuk membeli rumah tersebut. Tentunya yang tak kalah penting dalam menawarkan prumahan kepada calon konsumen adalah faktor pribadi seperti pembeli punya pekerjaan tetap agar dapat membayar cicilan rumah secara teratur dan pembeli memiliki cukup usia dalam memutuskan untuk memiliki rumah. Setelah itu adalah faktor psikologis konsumenpun turut menjadi penyebab seseorang untuk memiliki atau membeli rumah tersebut yaitu pembeli ingin diakui, dihargai saat telah memiliki rumah sendiri selain ingin adanya rasa aman dan terlindungi jika sudah memiliki rumah sendiri. 


\section{DAFTAR PUSTAKA}

Alma, Buchari. 2011. Manajemen Pemasaran dan Pemasaran Jasa. Bandung : Alfabeta

Arikunto, Suharsimi. 2008. Prosedur Penelitian : Suatu Tinjauan Praktik. Jakarta: Rineka Cipta

Kasmir. 2009. Manajemen Perbankan. Jakarta : PT Raja Grafindo Persada

Kotler, Philip. 2008. Manajemen Pemasaran. Alih Bahasa Hendra Teguh, Ronny

A. Rusli dan Benyamin Molan, Edisi Milenium, Prenhallindo : Jakarta.

Kotler, Philip dan Armstrong, Gary. 2004. Prinsip-prinsip Pemasaran I. Alih Bahasa Damos Sihombing, Edisi Kedelapan, Erlangga : Jakarta.

Lamarto, Yohannes. 2006. Prinsip Pemasaran. Jakarta:LP3ES

Lamb, et. al. 2010. Pemasaran. Buku 1. Jakarta: Salemba Empat

Lupiyoadi, Rambat. 2009.Management Pemasaran Jasa Teori dan Praktik. Jakarta:SalembaEmpat

Mursid, 2005.Manajemen Pemasaran. Jakarta : Bumi Aksara

Notoatmojo, 2005.Metodologi Penelitian Kesehatan : Rineka. Cipta : Jakarta

Saladin, Djaslim dan Yevis Marty Oesman. 2004. Intisari Pemasaran. Edisi Kedua, Media IPTEK : Bandung.

Sugiyono, 2011, Metode Penelitian Bisnis, Bandung, Alfabeta.

Sunyoto, Danang, 2013. Perilaku Konsumen, CAPS (Center of Academy Publishing Service), Yogyakarta

Swastha, Basu. 2008. Azas-Azas Marketing. Yogyakarta : Liberty

Swastha, Basu DH dan Irawan. 2003. Manajemen Pemasaran Modern. Yogyakarta: Liberty

Tjiptono, Fandy, 2006. Manajemen Pemasaran Jasa. Malang : Bayumedia Publishing

Teguh, Hendra 2007. Manajemen Pemasaran. Jakarta : PT Prenhallindo 